\title{
4. Local food prices
}

\section{PART I. BACKGROUND AND OVERVIEW}

\subsection{Introduction}

Food is the most important expense for workers in almost all developing countries. For this reason, ascertaining local food prices is a major part of the primary data collection for a living wage study in our methodology. This chapter describes how to determine food prices to use to estimate the cost of a living wage model diet (described in Chapter 3).

\subsubsection{Why collect local food prices}

There are several reasons why living wage studies collect local food prices. First, relevant, reliable, and recent prices for a wide variety of foods are rarely available from other sources. Second, even when food prices are reported on a regular basis, they are usually only reported for a restricted number of foods and often only for the capital city. Third, we have found that prices reported by government and NGOs are typically higher than workers actually pay, since workers often buy food from different locations and in different qualities and quantities. In our living wage methodology a special effort is made to ascertain food prices for a basic acceptable quality level that reflect how cost-conscious workers typically shop for food. This is not done in government statistics that are mainly concerned with tracking changes in food prices for CPI and so usually follow prices of easily identifiable foods (e.g. 125 gram Kraft cheese box; one kilo of Maharajah brand rice; Uha brand soybean oil sold in a prepackaged plastic one liter bottle).

\subsubsection{Collecting local food prices that mimic the way that cost-conscious workers buy food}

Our living wage methodology collects local food prices in a cost-effective way. At the same time, our methodology attempts to make sure that these prices are unbiased and representative of prices paid by workers. Prices are collected for a variety of qualities and quantities for each food from the types of venues where workers typically shop. In the analysis stage, the lowest priced foods of acceptable quality for each major food group are 
identified and subsequently used to calculate the cost of the living wage model diet. The idea of the methodology is to mimic the way in which cost-conscious workers who earn a living wage would shop for food. This includes buying foods that are on sale, in season, and of basic acceptable quality.

\subsubsection{Steps in a local food price survey}

Below is an overview of the steps in a local food price survey. Each step is explained in detail in the remainder of this chapter.

- Decide on which food items to price and adapt data collection forms. Examples of food price forms based on previous living wage studies are presented in Appendix 4.1. Different forms are provided for shops and supermarkets and for multi-vendor venues such as open air markets. These examples always need to be modified to be relevant for a location. Sometimes they need to be translated into the local language.

- Identify, hire and train local investigators to help in the collection of local food prices.

- Determine places that workers typically shop and make a schedule of venues to visit as part of the food price survey. Include one to two days of field testing and training in the schedule.

- Visit some venues where workers typically shop together with one or two local workers and decide on quantities and qualities of each food item to price.

- Modify data collection forms accordingly.

- Pretest data collection forms and procedures, and make necessary changes. Results from a pretest can often be used in final analysis.

- Collect food price data from local venues.

- Enter food prices into an Excel spreadsheet each evening during the food price survey. The least expensive food items to represent each food group will be identified during analysis.

- As food price collection continues, the supervisor can decide to stop collecting prices of more expensive items in each food group when this becomes clear.

- Check to see that investigators are collecting sufficient price points for each food item. This is especially important for foods with high price variability and foods that form a high proportion of food expenditure in the living wage model diet.

- Analyze food prices collected and determine price per kilo for each food item, and based on this, identify the least expensive food(s) per edible gram in each major food group to include in the model diet. 


\subsection{Selecting Specific Food Items on Which to Collect Prices}

Model diets (Chapter 3) are always comprised of major food groups. They do not usually indicate specific food items. For example, model diets include vegetables, but do not specify which vegetables. Model diets include dairy, but do not usually indicate whether this is fresh milk, powdered milk, UHT milk, or cheese or yogurt. Guidance is provided below on how to decide on specific foods for which to collect prices. In general, the specific foods selected for pricing should be relatively inexpensive, commonly consumed and available, and culturally acceptable. At a later stage, the least expensive acceptable foods in each food group would be selected to include in the living wage model diet.

\subsubsection{Fruits and vegetables}

There is almost always a wide variety of fruits and vegetables to choose from. To begin with, prices should be collected for many fruits and vegetables (except especially expensive ones). Analysis of the prices collected will enable selection of the least expensive fruits and vegetables to include in the model diet.

It is worth noting that since fruits and vegetables vary greatly in proportion edible, there may be a difference between the least expensive fruits and vegetables per purchased gram and the least expensive per edible gram. This means that the proportion edible needs to be considered when selecting the least expensive fruits and vegetables to include in a model diet.

It is also worth noting that in some countries, including India, Bangladesh, and Pakistan, tomato and onion are used like spices and eaten in almost every meal. Therefore, small amounts of tomato and onion should be included in the model diet even if they are not the least expensive.

\subsubsection{Beans and pulses}

Beans and pulses are inexpensive sources of proteins, and so usually an important part of low-cost nutritious diets. The beans or pulses included in a model diet should be relatively inexpensive for this food group and commonly eaten by workers. When beans or pulses are an important part of the diet, it is appropriate to include two types of beans or pulses in a model diet. For example, in the Dominican Republic we used equal quantities of black beans and pinto beans; in Kenya, where many different beans are sold, we used equal quantities of red kidney beans (which were found in all markets) and the least expensive other bean found in each shop. 


\subsubsection{Oils and fats}

Normally only one oil is included in a model diet. It is usually an inexpensive vegetable oil that is of acceptable quality to workers. The type of oil included varies across countries. In Malawi, we used cooking oil sold in open air markets from a large container. In Kenya, we used solid cooking oil sold in chunks in shops. In the Dominican Republic, we used soybean oil sold in a 128 ounce prepackaged plastic bottle. In Mauritius, we used vegetable oil sold in a one liter prepackaged plastic bottle.

\subsubsection{Meats, chicken, and fish}

It is necessary to identify early in the fieldwork the cuts and types of meats that are relatively inexpensive, and commonly eaten by workers and acceptable to them, so that prices can be collected for these. Note that prices should be collected only for animal products that are culturally acceptable. Beef is not acceptable in most of India. Pork is not acceptable in Muslim countries.

In Malawi, small dried fish that are eaten whole turned out to be the most commonly eaten inexpensive animal product. These small dried fish had the added advantage of providing needed calcium, since milk was imported and very expensive in Malawi. In countries where freezers are common, frozen chicken or frozen fish might be less expensive than fresh chicken and fresh fish, as we found in living wage studies in South Africa and the Dominican Republic.

\subsubsection{Eggs}

When different types of eggs are sold, such as chicken eggs, duck eggs, organic eggs, and 'industrial' eggs, the least expensive widely eaten type should be selected. In countries where the weight of eggs is not listed on a package, eggs should be weighed during fieldwork to determine average number of grams per egg and therefore cost per kilo.

\subsubsection{Milk}

Milk is almost always used to represent dairy products. Milk can be powdered, fresh, evaporated, or UHT. Use the type of milk that is least expensive per liter, provided that it is widely available and commonly used. For powdered milk, the quantity of powdered milk that makes one liter of milk when water is added should be noted. This is usually indicated on the package. In some countries yogurt and/or cheese are also included in model diets. 


\subsubsection{Grains}

The main grain eaten in a country is usually common knowledge. Researchers need to be careful in countries where there are regional differences in diets. For example, while rice is the most important grain in China, there are regions where wheat is more important. Also, in some countries, people typically eat more than one grain daily. In India, rice and wheat (for chapatti and nan, flat breads made from wheat flour) are both important and therefore both rice and wheat should be included in a model diet for most of India.

The quality and consequently the cost per kilo of grains such as rice and wheat can be quite different. This means that prices need to be collected for several acceptable and relatively inexpensive varieties. In this, it is useful to ask vendors and workers about which widely available varieties of rice and wheat are felt to be decent.

In locations where grains need to be milled, the cost of milling needs to be ascertained. We found, for example, that workers in Malawi bought maize that needed to be milled and workers in India bought wheat that needed to be milled.

\subsubsection{Sugar}

Both brown sugar and white sugar are usually available. Prices should be collected for both of these until it becomes clear which is less expensive.

\subsubsection{Summary}

Table 4.1 summarizes the above discussion. Suggestions are provided on the number of food items to include in a living wage model diet for each major food group together with examples and comments.

\section{PART II. COLLECTING LOCAL FOOD PRICES}

\subsection{Selecting Venues Where Workers Buy Food}

\subsubsection{Types of venues where workers buy food}

Workers buy food in a variety of settings. In some parts of the world, workers buy food mainly in open air markets. In other parts of the world, workers buy food mainly from street vendors, or from small neighborhood stores, and in other parts of the world, workers buy mainly from supermarkets.

Different types of foods are typically sold in several different types of venues. For example, workers might buy meats from small local butchers, fruits and vegetables from green grocers or open air markets, and staples 
Table 4.1 Summary regarding food items on which to collect local food prices

\begin{tabular}{|c|c|c|c|}
\hline Food group & $\begin{array}{l}\text { Number } \\
\text { food items } \\
\text { in typical } \\
\text { living wage } \\
\text { model diet }\end{array}$ & Comments & Examples \\
\hline $\begin{array}{l}\text { Main grain } \\
\text { (ground or } \\
\text { whole) }\end{array}$ & $\begin{array}{l}1-3 \text { main } \\
\text { cereals }\end{array}$ & $\begin{array}{l}\text { If ground after purchase, } \\
\text { grinding cost should } \\
\text { be included in cost. } \\
\text { Choose acceptable but } \\
\text { inexpensive qualities on } \\
\text { which to collect prices. }\end{array}$ & $\begin{array}{l}\text { Wheat and maize } \\
\text { are sometimes } \\
\text { ground into flour } \\
\text { after purchase. } \\
\text { Rice sometimes } \\
\text { needs to be husked } \\
\text { and cleaned after } \\
\text { purchase. }\end{array}$ \\
\hline $\begin{array}{l}\text { Prepared } \\
\text { grain }\end{array}$ & $0-2$ & $\begin{array}{l}\text { Depends on food habits } \\
\text { and development level. } \\
\text { Often not included at } \\
\text { low development level. }\end{array}$ & Bread, noodles \\
\hline $\begin{array}{l}\text { Legumes, } \\
\text { beans, } \\
\text { pulses and } \\
\text { nuts }\end{array}$ & $1-2$ & $\begin{array}{l}\text { Cheap source of quality } \\
\text { protein. Choose } 1 \\
\text { or } 2 \text { inexpensive but } \\
\text { common varieties. }\end{array}$ & Beans, pulses, nuts \\
\hline $\begin{array}{l}\text { Roots and } \\
\text { tubers }\end{array}$ & $1-2$ & $\begin{array}{l}\text { Amount consumed varies } \\
\text { greatly across } \\
\text { countries. }\end{array}$ & $\begin{array}{l}\text { Potato, cassava, sweet } \\
\text { potato }\end{array}$ \\
\hline $\begin{array}{l}\text { Starchy fruit } \\
\text { or vegetable }\end{array}$ & $0-2$ & $\begin{array}{c}\text { Optional. Important in } \\
\text { some countries only. }\end{array}$ & Plantains \\
\hline Oils and fats & 1 & $\begin{array}{l}\text { Choose inexpensive, } \\
\text { common cooking oil of } \\
\text { acceptable quality. }\end{array}$ & $\begin{array}{l}\text { Soybean oil, corn oil, } \\
\text { peanut oil }\end{array}$ \\
\hline Sugar & 1 & $\begin{array}{l}\text { Choose least expensive, } \\
\text { common sugar. Ignore } \\
\text { confectionaries. }\end{array}$ & $\begin{array}{l}\text { Brown sugar or white } \\
\text { sugar }\end{array}$ \\
\hline Vegetables & $3-4$ & $\begin{array}{l}\text { Choose at least } 1 \text { green } \\
\text { leafy and } 1 \text { non- } \\
\text { green leafy vegetable. } \\
\text { Choose least expensive } \\
\text { vegetables per edible } \\
\text { gram. }\end{array}$ & $\begin{array}{l}\text { Green leafy } \\
\text { vegetables: spinach, } \\
\text { kale, cabbage. } \\
\text { Non-green leafy } \\
\text { vegetables: eggplant, } \\
\text { tomato, onion. }\end{array}$ \\
\hline
\end{tabular}


Table 4.1 (continued)

\begin{tabular}{|c|c|c|c|}
\hline Food group & $\begin{array}{l}\text { Number } \\
\text { food items } \\
\text { in typical } \\
\text { living wage } \\
\text { model diet }\end{array}$ & Comments & Examples \\
\hline & & $\begin{array}{l}\text { In some countries, } \\
\text { tomatoes and onions } \\
\text { are used like spices - in } \\
\text { the sense that they are } \\
\text { included in almost every } \\
\text { meal. Small amounts of } \\
\text { these should be included } \\
\text { in the model diet in such } \\
\text { countries. }\end{array}$ & \\
\hline Fruits & $1-2$ & $\begin{array}{l}\text { Choose least expensive } \\
\text { per edible gram. Often } \\
\text { seasonal and banana. }\end{array}$ & $\begin{array}{l}\text { Banana (year round), } \\
\text { mango, apple, } \\
\text { orange }\end{array}$ \\
\hline $\begin{array}{l}\text { Meats and } \\
\text { fish }\end{array}$ & $1-3$ & $\begin{array}{l}\text { Choose least expensive } \\
\text { types of meats and/or } \\
\text { fish (considering waste) } \\
\text { of acceptable quality. }\end{array}$ & $\begin{array}{l}\text { Dried fish and dried } \\
\text { meat have more } \\
\text { calories and } \\
\text { nutrients than fresh } \\
\text { fish or meat - so can } \\
\text { be more economical } \\
\text { even when more } \\
\text { expensive per gram. } \\
\text { Small fish not } \\
\text { always considered } \\
\text { palatable/ } \\
\text { acceptable. }\end{array}$ \\
\hline Egg & 1 & $\begin{array}{l}\text { Inexpensive variety, } \\
\text { usually chicken egg. }\end{array}$ & Chicken egg, duck egg \\
\hline $\begin{array}{l}\text { Milk and } \\
\text { dairy }\end{array}$ & $1-2$ & $\begin{array}{l}\text { Usually milk. Whether } \\
\text { fresh, powdered, } \\
\text { evaporated, or UHT } \\
\text { milk depends on local } \\
\text { conditions and relative } \\
\text { prices. Other dairy is } \\
\text { sometimes also included. }\end{array}$ & $\begin{array}{l}\text { Milk, sour milk, } \\
\text { yoghurt }\end{array}$ \\
\hline Coffee/tea & 1 & $\begin{array}{l}\text { Choose least expensive } \\
\text { acceptable brand of tea } \\
\text { or coffee. Ignore sodas. }\end{array}$ & Coffee, tea \\
\hline
\end{tabular}


such as cereals, cooking oil, coffee and sugar from supermarkets. In urban India, for example, while workers typically buy most of their food in open air markets, they also often buy seasonal fruits and vegetables from itinerant street vendors, milk from a dairy, and vegetable oil and sugar from a small shop. In rural Malawi while workers typically buy most of their food in large weekly or biweekly open air markets, fruits and vegetables and staples that they run out of before the next market day are bought from small local open air markets and small shops. In Mauritius, workers mostly buy staples (powdered milk, rice, flour, breakfast cereals, pulses, sugar, oil and tea) from supermarkets; potatoes, vegetables and fruits from biweekly open air markets; meats and fish from butchers, cold storage shops and supermarkets; eggs from open air markets and supermarkets; and bread from local shops. Where workers buy different foods depends on factors such as price, convenience/proximity, availability of credit, and storage possibilities at home that depend in turn on climate, housing, and ownership of a refrigerator.

\subsubsection{Selecting venues to visit to collect local food prices}

Differences in food shopping patterns around the world mean that it is not possible to specify a universal approach of where to collect local food price data. It is necessary to determine where and how frequently workers typically shop for each major food group. It is common in many countries to buy staples such as cereals, sugar and cooking oil (foods that store well) in larger quantities from supermarkets or shops where they are less expensive and to buy foods that do not store well and are eaten throughout the week such as fruits, vegetables, meats, and fresh milk from places near home such as from local shops, local markets and street vendors.

Names, locations and opening hours of supermarkets, neighborhood shops, and open air markets, where workers shop are needed to develop a schedule of venues to visit. Discussions with key informants and workers are the best way to determine where and how frequently workers shop for each type of food. Female workers are generally (but not always) better informants than male workers since women generally have greater responsibility for shopping and cooking.

Based on discussions with workers and key informants, researchers should have a good idea of the following information (see Table 4.2 for an example for the Dominican Republic):

1. Where workers shop for each of the following: cereals, bread, noodles, roots and tubers, legumes, meats, fish, milk, egg, vegetables, fruits, sugar, oil, and coffee/tea. 
Table 4.2 Example of types of venues where workers buy different foods, rural Dominican Republic (' $\checkmark$ ' indicates yes)

\begin{tabular}{|c|c|c|c|c|c|}
\hline $\begin{array}{l}\text { Food } \\
\text { group }\end{array}$ & $\begin{array}{c}\text { Specific } \\
\text { foods }\end{array}$ & Supermarket & $\begin{array}{l}\text { Small grocery } \\
\text { store }\end{array}$ & $\begin{array}{l}\text { Street } \\
\text { vendors }\end{array}$ & $\begin{array}{c}\text { Fresh air } \\
\text { market }\end{array}$ \\
\hline Cereals & $\begin{array}{l}\text { Rice/ } \\
\text { Maize }\end{array}$ & $\checkmark$ & $\checkmark$ & & \\
\hline Bread & Bread & $\checkmark$ & $\checkmark$ & & \\
\hline $\begin{array}{l}\text { Roots and } \\
\text { tubers }\end{array}$ & $\begin{array}{l}\text { Potato/ } \\
\text { Cassava }\end{array}$ & $\checkmark$ & $\checkmark$ & $\checkmark$ & \\
\hline $\begin{array}{l}\text { Starchy } \\
\quad \text { fruits \& } \\
\text { vegetables }\end{array}$ & $\begin{array}{l}\text { Green } \\
\text { plantains }\end{array}$ & $\checkmark$ & $\checkmark$ & $\checkmark$ & $\checkmark$ \\
\hline Pulses & Beans & $\checkmark$ & $\checkmark$ & & $\checkmark$ \\
\hline Dairy & Milk & $\checkmark$ & $\checkmark$ & & \\
\hline Eggs & Egg & $\checkmark$ & $\checkmark$ & $\checkmark$ & \\
\hline Meats & \begin{tabular}{|l|} 
Chicken \\
Salami
\end{tabular} & $\checkmark$ & $\checkmark$ & $\checkmark$ & \\
\hline $\begin{array}{l}\text { Fruits and } \\
\text { vegetables }\end{array}$ & Many & $\checkmark$ & $\checkmark$ & $\checkmark$ & $\checkmark$ \\
\hline Sugar & & $\checkmark$ & $\checkmark$ & & \\
\hline Oil & & $\checkmark$ & $\checkmark$ & & \\
\hline Beer & & $\checkmark$ & $\checkmark$ & & \\
\hline Coffee/tea & & $\checkmark$ & $\checkmark$ & & \\
\hline $\begin{array}{l}\text { Comment } \\
\text { on food } \\
\text { shopping } \\
\text { pattern }\end{array}$ & & $\begin{array}{l}\text { Supermarket } \\
\text { in city was } \\
\text { far from } \\
\text { banana } \\
\text { plantations } \\
\text { so workers } \\
\text { shopped at } \\
\text { super-market } \\
\text { once a } \\
\text { month. }\end{array}$ & $\begin{array}{l}\text { Workers } \\
\text { bought } \\
\text { mostly from } \\
\text { neighborhood } \\
\text { groceries close } \\
\text { to home. } \\
\text { These } \\
\text { groceries gave } \\
\text { credit, which } \\
\text { was important. }\end{array}$ & $\begin{array}{l}\text { There were } \\
\text { some } \\
\text { street } \\
\text { vendors- } \\
\text { but they } \\
\text { were often } \\
\text { not } \\
\text { available. }\end{array}$ & $\begin{array}{l}\text { Fresh air } \\
\text { market } \\
\text { in city - } \\
\text { far from } \\
\text { banana } \\
\text { plantations } \\
\text { so workers } \\
\text { did not } \\
\text { often shop } \\
\text { there. }\end{array}$ \\
\hline
\end{tabular}

2. How often and in what quantities workers typically buy each type of food from each type of vendor.

3. Names, locations and opening times of venues where workers shop.

It is assumed that it is easy to find street vendors, small neighborhood shops and small tuck shops since there are many of them, and so it is not 
necessary to collect names and addresses for these in advance. Nor is it necessary to identify in advance names of individual sellers in open air markets since vendors can be easily found when visiting such markets.

\subsection{Maximum Amounts of Each Food Item Purchased at a Time}

The unit price of food is affected by the quantity purchased. Unit food prices are generally lower when larger quantities are purchased. This means that it is often necessary to collect information for a range of quantities, at least at first, to find the lowest per kilo price. This information on size or quantity should be recorded in the data collection forms used when collecting local food prices.

We typically use some simple rules of thumb to help determine the maximum quantity to use to collect food price data. These are based on the quantity of each food item in the model diet and the length of time each food item keeps without spoiling.

1. For staple foods that keep for weeks or months without spoiling (e.g. cereals, cooking oil, sugar, coffee/tea), the quantity purchased should not exceed the amount needed by the reference family for about four weeks in the living wage model diet. Our feeling is that it is generally reasonable to assume that workers earning a living wage would have enough money and storage capacity to purchase a one month's supply of staple foods that store well.

2. For foods such as fruits, vegetables, meats and fish that spoil quickly, the maximum amount purchased should depend on how long an item can keep without spoiling. For example, meat and fish need to be eaten the same day when workers do not own a refrigerator (although dried fish and dried meat can be kept for several days without refrigeration).

3. We have found that workers in poor areas often purchase foods in tiny quantities and this is expensive per kilo. Often, this occurs at the end of the pay period when workers do not have enough money left to purchase larger quantities even though larger quantities are less expensive per kilo. We do not recommend collecting prices for tiny quantities, because workers earning a living wage would have enough money left at the end of the month to be able to buy larger quantities which are less expensive per kilo.

The above suggestions are meant to help in setting maximum quantities for collecting food price data. Obviously, some judgment is needed. Prices need to be collected for a range of quantities for each food in order to find the lowest per kilo for each food. Observing the amount of shelf space in 
supermarkets and shops devoted to different quantities can be very useful. In Mauritius, for example, we found that most rice in supermarkets was sold in 5 kilo bags - and we used this as the maximum quantity to price for rice.

\subsection{Quality of Foods to Collect Prices for}

Food prices obviously vary by quality. Filet mignon costs more than chuck, and boneless chuck costs more than untrimmed chuck with bone. Big fish cost more than little fish. The quality of food selected for a living wage model diet should be the lowest quality that is considered acceptable/decent to workers. For example, an acceptable quality rice should be selected rather than the highest quality rice; inexpensive vegetable oil should be selected rather than expensive olive oil; and frozen chicken rather than fresh chicken should be selected when frozen chicken is less expensive and workers have refrigerators. Note that food that is rotten or of dubious origin and so a possible threat to health should never be considered acceptable quality. Selecting the quantities and qualities of foods on which to collect prices is normally done in the initial days of pretesting. It is useful to have local workers accompany researchers to show them what they typically purchase.

\subsection{Fieldwork Logistics}

This section explains the basic steps in preparing for and carrying out a survey of food prices in local markets.

\subsubsection{Modify food price data collection forms}

The first step, before the fieldwork begins, is to modify the data collection forms provided at the end of this chapter for local conditions and if necessary translate them into the local language. Note that even after preliminary modifications, the data collection forms are likely to need further modification after field testing to include more precise quantities and qualities.

\subsubsection{Identify and train field investigators}

It is necessary to identify and train local field investigators to help in the collection of local food prices. Our experience shows that it is best to have two investigators working together to collect food prices. Having trained local investigators is also important so that they could be asked to collect additional food prices if this becomes apparent as being necessary during data analysis. 
Field investigators should be:

- Familiar with where and how workers shop for food

- Able to speak the local language

- Able to talk to key informants, workers, and vendors about food prices, food preferences and shopping habits of workers

- Able to enter food prices collected into an Excel spreadsheet

\subsubsection{Identify local workers to assist in collection of food prices}

We have found it extremely useful for local workers to accompany the researchers, especially during the first days of collecting food price data. Local workers can take researchers to the places they themselves buy food, and help obtain cooperation of local shopkeepers. An additional benefit of having workers involved in the collection of food prices is that their involvement increases the likelihood of workers and employers accepting the results of the study when it is finished, because they know how the data were collected.

\subsubsection{Select sales venues to visit}

Venues visited should reflect where workers typically shop for food. Section 4.3 describes how to determine where workers shop for food. Several venues for each type of market should be visited. It is not necessary to take a random sample of all possible venues. In fact, even for estimating CPI, 'many countries nevertheless continue to rely heavily on purposeful selection of outlets and products because random sampling may be too difficult and costly' (ILO et al., 2004, p. 24). The aim is to visit a variety of venues to reflect as far as possible the places that workers typically shop so that the prices collected are reasonably representative of prices that workers pay for food.

\subsubsection{Number of venues, number of sellers, and number of price points for each food item}

There are no hard and fast rules to indicate how many venues of each type of market to go to. We recommend at least five different venues for each type. For markets with many different sellers, such as open air markets or street vendors, prices of each food should be collected from several sellers in each market, because prices vary by seller. In this way, the average or typical price for each food item in each market/venue visited can be determined. We recommend collecting prices for each food item from two (or three) vendors in each multiple-vendor market. These vendors should not be adjacent to each other.

We recommend that a minimum of around 10 price points be collected 
for each common and relatively inexpensive food item (i.e. for foods that are good candidates to be included in a living wage model diet) in order to have a sufficient number of price points so that it is possible to exclude outliers and still be able to calculate representative food prices. There cannot be, however, a hard and fast rule on the number of price points to collect. The number of price points depends in part on the variability in food prices. A situation where very similar or exactly the same prices are found in markets for a particular food (say for milk, oil, sugar) is quite different than a situation where prices of particular foods (e.g. tomatoes, mangos, fish) vary considerably across markets. Collecting additional prices for foods with low price variability is unlikely to be very important. In contrast, it is important to collect additional prices for foods with high price variability. Also, it is worth noting that in some locations the number of possible price points is limited by the small number of different sales venues (such as supermarkets and open air markets) in the location.

\subsubsection{Pretest of local market survey}

One or two days should be set aside for a pretest. The purpose of a pretest is to identify the quality and quantities of food items to price, train investigators, test data collection forms and finalize procedures. As discussed above, it is very useful for workers to accompany researchers to shopping venues to help decide on types of foods and appropriate quantities and qualities of each food item to price. Problems encountered during the pretest should be discussed and resolved. Results from the pretest can often be used in final analyses.

\subsubsection{Times to avoid collecting food prices}

Food prices, especially for fresh products such as fruits and vegetables, can be volatile. For example, prices often spike around holidays and storms. In places where prices differ by time of day and/or day of the week, it is important to take this variability into consideration since the goal is to determine food prices that are representative of the prices workers typically pay.

\subsubsection{Day of week Food prices are often higher on weekends than on} weekdays (ILO et al., 2004). Although this might imply that food price data collection should not be done on weekends, this is not necessarily the case. Whether or not weekends should be avoided depends on when workers buy their food, since we are interested in determining food prices that workers pay. This means that food prices should be collected on the days of the week that workers typically buy their food, including weekends if this is when workers shop, even if prices are higher on weekends. 
4.6.7.2 Time of day Food prices often vary by time of day (ILO et al., 2004). They might be, for example, higher in the morning, before new shipments arrive and lower at the end of the day for perishables. For the most part, prices should be collected at the time of day that workers typically shop for their food. Note that differences in food prices during the day are not generally important for staples and nonperishables.

4.6.7.3 Days near holidays and storms Food prices are typically higher on days approaching holiday periods (ILO et al., 2004). Food prices should not be collected on these days. Food prices are also affected by major storms, being higher just before, during, and just after major storms. For this reason, food price data should not be collected on such days.

\subsubsection{Supervising and monitoring collection of food prices}

Data collection forms should be checked over by the supervisor or another investigator as soon as they are completed in order to identify and resolve any problems with the completed forms, such as unclear handwriting or columns left blank. It is important that corrections are done soon after forms are completed, while details are still clear in the mind of investigators. Data should be entered into the Excel spreadsheet every evening after fieldwork. Notes should be added for a particular food price when there is an explanation why a particular food price is unusually high or unusually low. It is also important to keep track of the number of prices collected and entered in the Excel worksheet for each food so as to identify common and relatively inexpensive foods with very few price points, so that future data collection can pay particular attention to these food items. For example, after two days of data collection in Kenya, we realized that very few prices for tomatoes and milk had been collected. Therefore, on subsequent days, price collectors particularly looked for these items in the markets they visited.

It is reasonable to stop collecting prices of especially expensive items, since they would not be selected to include in the model diet. This helps increase the speed of the fieldwork, because data would be collected on fewer items as fieldwork goes along.

\subsection{Other Considerations for Collecting Food Prices}

\subsubsection{Need to weigh foods when not sold by weight}

Some foods are sold by the piece, bunch, heap, or bag and not sold by weight. Since model diets are expressed in grams, it is important to weigh foods sold in this way, to ascertain their cost per kilo. Price collectors need a small kitchen scale and a bowl to weigh these items. Normally, 
at least three pieces should be weighed to determine the average weight and therefore cost per kilo. For example, when tomatoes are sold by the piece, the price collector/investigator should weigh at least three typically sized tomatoes and record both the price per tomato and the average weight per tomato for each seller. The same should be done for food sold by bunch such as spinach. Three average size bunches should be weighed, and the price per bunch and average weight per bunch should be recorded.

\subsubsection{Need for small budget to buy food}

Often it is necessary to purchase some food from vendors to find out food prices. This is especially likely to be necessary when vendors are busy. The need to buy from vendors differs by country. In some countries, vendors are willing to provide accurate information on food prices without any purchases (e.g. we found this to be the case in Kenya and Mauritius), while in other countries vendors are not willing to indicate prices unless something is purchased (e.g. we found this to be the case in Vietnam). In other countries prices per kilo are almost always posted (e.g. China). A small budget should be provided so that investigators can purchase some foods from vendors when this is necessary.

\subsubsection{Possible need to engage in bargaining}

In some places bargaining is an integral part of purchasing food. This is especially important in Africa and in the Middle East:

The principle is that [in places where price bargaining is common], price collection should be carried out in conditions that simulate as closely as possible situations in which real transactions actually take place. Price collectors should behave like regular purchasers by actually purchasing items to be priced and spread their purchases over the day to ensure representativeness. (ILO et al., 2004)

One approach that some national statistical offices in the Middle East use is to give field investigators a certain amount of money and ask them to purchase a list of food items, with the incentive that investigators can keep whatever they do not end up spending (ILO et al., 2004).

\subsubsection{Possible need to find milling charges for cereals}

In some countries, it is common for workers to purchase maize or wheat and have it milled after purchase. In such countries price collectors need to find the cost of milling. 


\section{PART III. COLLECTION AND ANALYSIS OF LOCAL FOOD PRICES}

\subsection{Description of Data Collection Forms}

\subsubsection{Information collected}

Data collection forms have been developed for collecting local food prices. There are different forms for different types of market/venue in order to make data collection easier. Appendix 4.1 provides examples of data collection forms for: (i) supermarkets and grocery shops that sell foods from many different food groups, and specialized shops that mainly sell one or a few different food groups (for example, butcheries, milk depots, green groceries, grain shops, etc.), (ii) open air markets with multiple vendors and street vendors.

\subsubsection{Forms for different types of markets}

4.8.2.1 Supermarket food price collection forms For supermarkets which sell a wide variety of foods - data collection forms should cover all foods. Brand name should be indicated because price per kilo differs by brand. Prices should be collected for at least two or three inexpensive brands for each food in each supermarket. Supermarket chains will often have their own relatively inexpensive brand, which should be included on the form. Price collectors should note on the form when an item is not available - so that it is clear that the investigator did not accidently forget to record this price. Supermarkets often run promotions that are attractive to workers, often at the end of the month. When a particular food item is on promotion/sale this should be noted on the form because this helps explain when a price is unusually low.

4.8.2.2 Small/medium size grocery store food price collection forms Data collection forms for small grocery stores are similar to those for supermarkets, even though such stores sell fewer items. When it is clear that certain items are not sold in small grocery stores in a locality, these items can be dropped from the forms. For example, frozen food was not sold in small grocery stores in the Dominican Republic, and so frozen food items were dropped from these forms.

\subsubsection{Specialty store food price collection forms Separate forms for} different types of specialty stores are useful. For example, there could be a form for butcheries, a different data collection form for green grocers, and a third data collection form for tuck shops - with different foods included in each form for each type of shop. These forms will be shorter than the 
forms for supermarkets or grocery stores because only food items sold in the particular type of specialty shop would be included.

4.8.2.4 Open air market food price collection forms Open air markets usually have many small vendors for each food item. For example, 10 or more vendors might be selling tomatoes. It is necessary to collect price information from two or three different sellers for each item, partly because prices differ across sellers and partly because price per kilo for food sold by the piece or bunch will differ even when price per piece or bunch is the same for all sellers, because each piece or bunch has a different weight. The sellers selected should not be adjacent to one another.

4.8.2.5 Street seller food price collection forms Price collection forms for street sellers should be similar to those for open air markets. Usually, information can be collected on one form for several street sellers selling the same item.

\subsection{Analysis of Local Food Prices}

There are two aims of the analysis of food prices: (i) to identify the least expensive foods in each major food group to include in the model diet, and (ii) to estimate cost per kilo for each food. In order to do this, it is necessary to determine the average/typical price that workers pay for each food item. This is done in several steps. Details for each step are discussed in the remainder of this section.

\subsubsection{Cleaning the data}

Data should be carefully scrutinized before analysis to look for possible 'outliers' that should be excluded from analysis, since these values are likely to be errors. An error could be due to incorrect units or kilos (e.g. price for 500 grams of rice might have been recorded as the price for one kilo of rice), or due to reporting error (e.g. shopkeeper provided poor information possibly out of misunderstanding), or due to transcription error (e.g. data was entered incorrectly on food price form or in Excel). It is not possible to set hard and fast rules on how to identify outliers. But values that are $30 \%$ or more above or below average deserve further scrutiny to make sure that they are not errors. Sometimes, explanations for outliers can be found. For example, prices of products 'on promotion' are usually lower than products not on promotion. Prices of food sold by the bunch or piece have considerable variation because of differing weights. If no explanation can be found for a price that is far outside the usual range, the outlier price should be deleted from further analysis. 


\subsubsection{Determining representative price for each food item}

Determining the representative price for each food item is done in two steps. First, a representative price for each venue is calculated in a way that mimics the way that price-conscious shoppers buy food. Second, these representative prices are averaged over all markets, possibly taking into consideration the relative importance of each type of market.

4.9.2.1 Representative prices for venues with one 'seller' For venues with one 'seller' (such as supermarkets, specialty shops and grocery stores) the representative price for each food item should be the price of the least expensive acceptable brand/variety and quantity. For example, supermarkets always sell several brands of rice. Each brand often has several types of rice (e.g. long grain, short grain, jasmine, or basmati), and each of these is often sold in different quantities (e.g. $1 \mathrm{~kg}, 5 \mathrm{~kg}$ and $10 \mathrm{~kg}$ ). So, there may be many prices of rice in each supermarket. We assume that cost-conscious shoppers would normally purchase the least expensive acceptable quality rice. Therefore, to represent the price per kilo that a cost-conscious worker would likely pay for rice, the researcher should select the least expensive acceptable quality rice for the least expensive quantity provided the quantity is not more than the maximums suggested in Section 4.4.

\subsubsection{Representative prices for multi-vendor markets and street} sellers Multi-vendor venues such as open air markets or street sellers may sell different varieties of the same food item. For example, open air markets and specialty stores may sell several different varieties of rice from large gunny sacks. A two-step process is used to determine the representative price of each food item sold in a multi-vendor market.

1. First, for each vendor in open air market A, select the least expensive acceptable variety/brand of each food item as the representative price of that food item for that vendor. For example, if vendor A sells rice, the price per kilo of the least expensive acceptable rice s/he sells should be selected as the 'representative' price of rice for vendor A. Similar calculations should be done for each vendor for each food item.

2. Second, to get the price for each food item for open air market A, calculate the 'representative' (mean or median) price per kilo for that food item over all vendors from whom prices were collected in the market A. ${ }^{1}$

\subsubsection{Determining typical price of each food item across all venues Once} a representative price for each food item for each venue has been determined, the next step is to aggregate these data over all venues. We recommend using the trimmed mean (whereby the average price is calculated after removing a percentage of the highest and the lowest prices) or the 
median. In this way, food prices are determined in a way that is not unduly influenced by unusually high or unusually low prices. There is a trimmean command in Excel.

\subsubsection{Selecting specific foods to include in each food group in model diet}

The least expensive food item or items per edible gram in each major group should be selected to represent each major food group in the living wage model diet. This might be kidney beans for legumes, potatoes for roots and tubers, and banana and oranges for fruits.

\subsection{Examples: Selecting Foods to Include in the Model Diet}

\subsubsection{Single-vendor market example for rice}

Table 4.3 provides a hypothetical example of how to select the representative price of rice for one supermarket and two minimarkets. Many varieties of rice are sold in each venue both in bulk and in packages, which is not unusual for a staple food such as rice. Rice is sold in different quantities in these markets, with larger quantities less costly per kilo. This is typical in most locations.

The quality of one variety of rice sold in bulk in this example (i.e. quality 3 ) is not acceptable and it is therefore excluded. The lowest price for acceptable quality rice in this example is 70 in Supermarket A, 85 in Minimarket B, and 80 in Minimarket C.

\subsubsection{Multiple-vendor market for rice}

Table 4.4 provides a hypothetical example of an open air market (venue D) with multiple sellers of rice. Rice prices of three vendors are shown. Two varieties of rice (Malwa and broken rice) are excluded from analysis because they are not acceptable to workers. The lowest price of acceptable rice is 70 from vendor 1,75 from vendor 2 , and 80 from vendor 3 . The average lowest price across these three vendors in venue $\mathrm{D}$ is 75 .

Table 4.5 provides a hypothetical example of how to determine the price of rice based on prices for 13 venues. The trimmed mean of the lowest price per kilo from each venue is 73.9. This should be used as the cost of a kilo of rice in the living wage model diet.

\subsubsection{Selecting vegetables to include in the model diet}

Table 4.6 provides a hypothetical example of how to determine prices per kilo for vegetables. In this example information is provided for 11 venues. Notice that vegetables sold in only a few venues (pumpkin, spinach and eggplant) were excluded from analysis because it is not appropriate to include foods in a model diet that are not widely available. The trimmed 
Table 4.3 Hypothetical example: Determining price of the least expensive acceptable variety of rice in three shops

\begin{tabular}{|c|c|c|c|c|}
\hline Type/brand/quality of rice & & $\begin{array}{c}\text { Supermarket } \\
\text { A }\end{array}$ & $\begin{array}{l}\text { Mini market } \\
\text { B }\end{array}$ & $\begin{array}{l}\text { Mini market } \\
\quad \mathrm{C}\end{array}$ \\
\hline Rice sold in bulk & Quantity & Price per kg & Price per $\mathrm{kg}$ & Price per $\mathrm{kg}$ \\
\hline Rice quality 1 (Sindano) & $1 \mathrm{~kg}$ & 120 & NA & NA \\
\hline Rice quality 2 (Pakistan) & $1 \mathrm{~kg}$ & 110 & NA & NA \\
\hline Rice quality 2 (Indian) & $1 \mathrm{~kg}$ & 70 & NA & NA \\
\hline Rice quality 2 (5 star) & $1 \mathrm{~kg}$ & 80 & 85 & NA \\
\hline Rice quality 2 (Moshi) & $1 \mathrm{~kg}$ & 80 & NA & 80 \\
\hline $\begin{array}{l}\text { Rice quality } 3 \text { (Broken - not } \\
\text { considered acceptable by workers) }\end{array}$ & $1 \mathrm{~kg}$ & NA & 60 & 55 \\
\hline \multicolumn{5}{|l|}{ Packaged rice } \\
\hline Rice quality 1 (Pearl) & $1 \mathrm{~kg}$ & 190 & NA & NA \\
\hline Rice quality 1 (Pearl) & $5 \mathrm{~kg}$ & 179 & NA & NA \\
\hline Rice quality 1 (Pishori Cil) & $2 \mathrm{~kg}$ & 180 & 190 & NA \\
\hline Rice quality 1 (Dawaat) & $1 \mathrm{~kg}$ & 120 & NA & 130 \\
\hline Rice quality 1 (Dawaat) & $2 \mathrm{~kg}$ & 100 & 135 & NA \\
\hline Rice quality 1 (Pishori Mwea) & $1 \mathrm{~kg}$ & 125 & NA & 120 \\
\hline Rice quality 1 (Pishori Mwea) & $2 \mathrm{~kg}$ & 140 & 155 & NA \\
\hline Rice quality 1 (Pishori Mwea) & $5 \mathrm{~kg}$ & NA & 145 & 160 \\
\hline $\begin{array}{l}\text { Price of least expensive acceptable } \\
\text { quality rice in each shop }\end{array}$ & & 70 & 85 & 80 \\
\hline
\end{tabular}

Note: NA indicates not available.

mean of the least expensive price of each vegetable across venues is considered the representative price for each vegetable. It is divided by the proportion edible to get a representative price per edible kilo. In this example, the least expensive green leafy vegetable is cabbage (17.8 per edible kilo), and the least expensive non-green leafy vegetable is tomato ( 78.9 per edible kilo). The next least expensive vegetable is kale (41.0 per edible kilo). These three vegetables would be selected to include in the model diet.

\subsection{Possible Adjustment of Local Food Prices for Seasonality}

Although food prices collected are intended to be representative of typical prices during the year, they are collected over a relatively short period of 
Table 4.4 Hypothetical example of determining the cost of the least expensive acceptable variety of rice in a venue with three vendors in venue $D$

\begin{tabular}{|c|c|c|c|c|}
\hline \multirow[t]{2}{*}{ Type/brand/quantity of rice } & \multirow[b]{2}{*}{ Quantity } & \multirow{2}{*}{$\frac{\text { Vendor } 1}{\text { Price per } \mathrm{kg}}$} & \multirow{2}{*}{$\frac{\text { Vendor } 2}{\text { Price per kg }}$} & \multirow{2}{*}{$\begin{array}{c}\text { Vendor } 3 \\
\text { Price per k }\end{array}$} \\
\hline & & & & \\
\hline Rice quality 1 & $1 \mathrm{~kg}$ & 120 & 125 & 130 \\
\hline Rice quality 2 (Indian) & $1 \mathrm{~kg}$ & 70 & 75 & NA \\
\hline Rice quality 2 (5 star) & $1 \mathrm{~kg}$ & 85 & 85 & NA \\
\hline Rice quality 2 (Moshi) & $1 \mathrm{~kg}$ & 80 & NA & 80 \\
\hline $\begin{array}{l}\text { Rice quality } 3 \text { (Malwa - not } \\
\text { considered acceptable by } \\
\text { workers) }\end{array}$ & $1 \mathrm{~kg}$ & 60 & NA & 65 \\
\hline $\begin{array}{l}\text { Rice quality } 3 \text { (broken - not } \\
\text { considered acceptable by } \\
\text { workers) }\end{array}$ & $3 \mathrm{~kg}$ & 50 & 55 & 60 \\
\hline \multicolumn{2}{|l|}{$\begin{array}{l}\text { Price of least expensive acceptable } \\
\text { rice for each vendor }\end{array}$} & 70 & 75 & 80 \\
\hline \multicolumn{2}{|l|}{ Representative price of rice Venue $\mathrm{D}$} & 75 & & \\
\hline
\end{tabular}

Note: NA indicates not available.

Table 4.5 Hypothetical example: Determining the price of rice per kilo to include in model diet in a location with 13 venues using $20 \%$ trimmed mean

\begin{tabular}{|c|c|c|c|c|c|c|c|c|c|c|c|c|c|}
\hline Venue & A & B & $\mathrm{C}$ & $\mathrm{D}$ & $\mathrm{E}$ & $\mathrm{F}$ & G & $\mathrm{H}$ & I & $\mathrm{J}$ & $\mathrm{K}$ & $\mathrm{L}$ & M \\
\hline $\begin{array}{l}\text { Representative } \\
\text { price for each } \\
\text { venue }\end{array}$ & 70 & 85 & 80 & 75 & 70 & 72 & 85 & 80 & 65 & 68 & 72 & 70 & 71 \\
\hline $\begin{array}{l}\text { Trimmed mean } \\
(20 \%) \text { over all } \\
\text { venues }\end{array}$ & & & & & & & 73.9 & & & & & & \\
\hline
\end{tabular}

time (usually 5 to 10 days), and so some consideration of possible seasonal variation of food prices is required. One way in which our methodology reduces the effect of seasonal variation of food prices is that less expensive food items at the time of the food price survey are included in the model diet. This means that foods that are out of season (and so relatively expensive) are generally excluded from the model diet. 


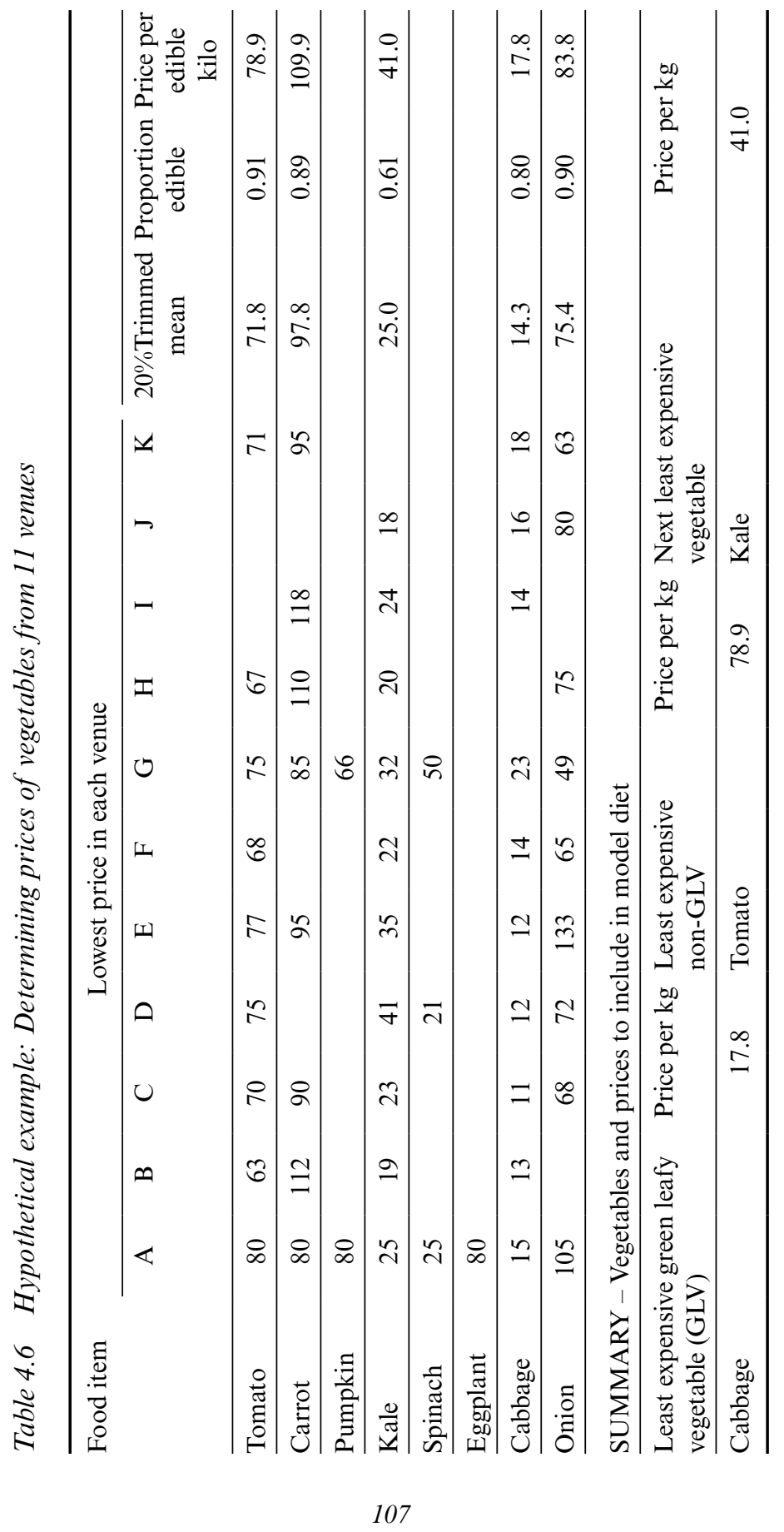


Use of seasonal foods does not, however, necessarily account for all price variations over the year. The price of some foods purchased throughout the year such as maize, rice and fish can vary over the year in some countries. Prices of vegetables and fruits can be higher on average in some seasons even when using seasonal items. This means that an analysis of food prices by season should be done using secondary data sources, to see if prices for different foods collected in a local market survey are typical, relatively high or relatively low for the year. Adjustments should be made to food prices for food items with large seasonal variations - in order to arrive at more average/typical prices throughout the year.

Ascertaining seasonality in food prices can be best done using monthly food prices for several years - when such data are available which is not unusual. We found such prices for Kenya and Mauritius on government websites, and for Malawi on an NGO website. In China average monthly food prices for 50 cities are reported by the national statistical office. Analyzing monthly prices for a food item over several years is a good way to determine if there is a seasonal pattern as well as to see if the same seasonal pattern is found consistently every year. The ratio of the price in the study month to the average price of a particular food item over a calendar year of over a 12 month period (starting 6 months before the month of data collection in order to reduce the effect of any trend over time in food prices because of inflation) provides a good indication of the extent to which prices collected are representative of prices throughout the year and so if an adjustment is needed for seasonality. This ratio should be calculated for several years - to be sure that the ratio reflects consistent seasonal differences.

It is important to keep in mind that even when there is a strong seasonal price variation for a particular food, the price of this food at the time of a food price survey may be average for the year. For example, the price of onions in Kenya has a strong consistent seasonal pattern related to harvest times, but the price of onion in March, the month of the local food price survey for our living wage study, was average for the year (see example below).

One possible problem that researchers should be aware of is that governments sometimes sell foods at subsidized prices. This often affects market prices and therefore seasonality in prices for these foods in years when this is done. For example, in Malawi the government was selling large quantities of maize at a reduced price at the time of our local food price survey and this had the effect of negating the high price for maize usually found at this time of year.

As a supplement to analyzing food price data by month, key informants should be asked about seasonal patterns in food prices, because this is often common knowledge. In addition, published articles can also be useful as we found in Kenya (see example below). 


\subsubsection{Example 1: Adjusting local food prices for seasonality: Kenya}

We collected food prices in the Lake Naivasha area of Kenya in March 2014 for a living wage study. Two sources were used to help determine if these March food prices were reasonably representative of prices throughout the year:

1. Monthly food prices were reported by Kenya National Bureau of Statistics (KNBS, 2015) on its website for 2012-2013. These food prices are used to estimate urban CPI.

2. Academic journal article that analyzed seasonality of wholesale fruit and vegetable prices in Nairobi, Mombasa and Kisumu for 1994-2003 (Mathenge and Tschirley, 2006).

We calculated the ratio of the March price to average price for the year (September to September bracketing March) for each food item in the KNBS data. This ratio indicated that March prices were similar to average price throughout the year for beef, offal, milk, maize flour, sugar, tomato, and cabbage. There were too few months of data to draw conclusions for mango, carrot, spinach, and kale. The price of potato was slightly higher in March than its average price for the year (by about 5\%), although it was difficult to draw conclusions on this because potato prices were not reported for October-January for either 2012 or 2013.

Partly because of the incomplete nature of KNBS data, we also relied on Mathenge and Tschirley (2006) who analyzed food price data for seven foods (banana, orange, kale, tomato, onion, cabbage, and potato) for 10 years from three cities (Nairobi, Mombasa, and Kisumu). They found consistent seasonality in prices for potato and vegetables but not for either fruit.

Based on our analysis of seasonality in food prices, we decided to reduce the prices we collected in March by one-third for kale/spinach and by 5\% for potato. We did not reduce the price we collected for cabbage despite its generally higher price in March, because the price of cabbage observed in our local market survey was very low at only KSh11.5 per kilo, about $\$ 0.06$ per pound.

\subsubsection{Example 2: Adjusting of local food prices for seasonality: Malawi}

We collected food prices in the areas surrounding tea estates in Southern Malawi in January 2014. To determine whether January prices were reasonably representative of prices throughout the year, we used monthly food price data collected by the Center for Social Concern (CfSC) for Blantyre city (closest location to tea estate area in these data) from January 2008 (earliest available date) to December 2013 (latest available date). We 
calculated the ratio of the January price relative to the average price for the July to June period that bracketed January. We found that the January price was reasonably similar to the average price throughout the year for fish, sugar, milk, cooking oil, and tea. The January price was on average around $10 \%$ higher than the average price for the year for maize, beans and cassava and around 30\% higher for rape, but these percentages varied greatly from year to year. In light of these results, we decreased January prices for beans and cassava by $10 \%$ and left unchanged all other January prices. We did not change the green leafy vegetable prices because we used the lowest price for all types of green leafy vegetables to cost our model diet regardless of whether this was pumpkin leaves, okra leaves, mustard leaves, rape, etc.

We looked more carefully at seasonality in the price of maize, partly because maize is a large expense for families in Malawi as it is the main staple food, and partly because there is a common belief in Malawi that the price of maize increases in the months before a new harvest and falls during and right after a new harvest. We did indeed find this pattern in CfSC data - but this pattern was more complicated than the simple pattern we heard about. We found that maize prices tended to spike in February and March. We also found that prices tended to fall sharply for two or three months after a new harvest. But the seasonal pattern described did not occur every year. For example, maize price did not increase sharply before the new harvests in 2010, 2011 or 2012 and it did not decrease sharply around the time of the new harvest in 2010 or 2012. Part of the reason for these surprising years may be traceable to government intervention as the Agricultural Development and Marketing Corporation (ADMARC) releases maize on to the market from time to time to reduce the market price. We found ADMARC was doing this in January 2014 at the time of our local food price survey. All of this meant that it was not possible to know if the January 2014 maize prices we observed were or were not typical for January, and for this reason we decided not to adjust the price of maize we observed.

\section{NOTE}

1. The reason why the least expensive vendor in a multi-vendor market is not selected is that shoppers cannot easily compare prices per kilo in such markets. This is especially true for foods sold by the bunch or piece. 


\section{APPENDIX 4.1 DATA COLLECTION FORMS FOR LOCAL FOOD PRICES}

\section{Table 4A.1 Example of multi-vendor form to collect food price data for cereals}

\begin{tabular}{|c|c|c|c|c|c|c|c|}
\hline \multicolumn{8}{|c|}{ Modify to include main cereals for local area } \\
\hline \multicolumn{8}{|c|}{ Cereals (rice, wheat, maize, bread, noodles) } \\
\hline \multicolumn{8}{|l|}{ Market name } \\
\hline \multicolumn{8}{|l|}{ Market location } \\
\hline \multicolumn{8}{|c|}{ Seller's address/location (if fixed location) } \\
\hline \multicolumn{8}{|c|}{ Investigator's name } \\
\hline \multicolumn{8}{|l|}{ Date completed } \\
\hline \multirow{2}{*}{\multicolumn{2}{|c|}{$\begin{array}{l}\text { Seller's address } \\
\text { (if fixed) }\end{array}$}} & \multirow{2}{*}{\multicolumn{3}{|c|}{ Seller 1}} & \multirow{2}{*}{\multicolumn{3}{|c|}{ Seller 2}} \\
\hline & & & & & & & \\
\hline & $\begin{array}{l}\text { Quality and } \\
\text { name (only } \\
\text { for acceptable } \\
\text { quality) }\end{array}$ & Quantity & Price & $\begin{array}{l}\text { Price } \\
\text { per kg }\end{array}$ & Quantity & Price & $\begin{array}{l}\text { Price } \\
\text { per kg }\end{array}$ \\
\hline \multicolumn{8}{|l|}{ Rice } \\
\hline & & & & & & & \\
\hline \multicolumn{8}{|l|}{ Wheat flour } \\
\hline \multicolumn{8}{|l|}{ Maize } \\
\hline & & & & & & & \\
\hline \multicolumn{8}{|l|}{$\begin{array}{l}\text { Maize milling } \\
\text { charge }\end{array}$} \\
\hline \multicolumn{8}{|l|}{$\begin{array}{l}\text { Noodles } \\
\text { (indicate type) }\end{array}$} \\
\hline $\begin{array}{l}\text { Bread } \\
\text { (indicate } \\
\text { if white or } \\
\text { brown) }\end{array}$ & & $\begin{array}{l}\text { Weight } \\
\text { of loaf in } \\
\text { grams and } \\
\text { number } \\
\text { of slices } \\
\text { per loaf }\end{array}$ & $\begin{array}{l}\text { Price } \\
\text { per } \\
\text { loaf }\end{array}$ & $\begin{array}{l}\text { Price } \\
\text { per kg }\end{array}$ & $\begin{array}{l}\text { Weight } \\
\text { of loaf in } \\
\text { grams and } \\
\text { number of } \\
\text { slices per } \\
\text { loaf }\end{array}$ & $\begin{array}{l}\text { Price } \\
\text { per } \\
\text { loaf }\end{array}$ & $\begin{array}{l}\text { Price } \\
\text { per kg }\end{array}$ \\
\hline \begin{tabular}{|l|} 
Buns \\
(indicate type)
\end{tabular} & & $\begin{array}{l}\text { Weight of } \\
\text { bun }\end{array}$ & $\begin{array}{l}\text { Price } \\
\text { per bun }\end{array}$ & $\begin{array}{l}\text { Price } \\
\text { per kg }\end{array}$ & $\begin{array}{l}\text { Weight } \\
\text { of bun }\end{array}$ & \begin{tabular}{|l|} 
Price \\
per bun
\end{tabular} & $\begin{array}{l}\text { Price } \\
\text { per kg }\end{array}$ \\
\hline & & & & & & & \\
\hline
\end{tabular}


Table 4A.2 Example of data collection form to collect cereal prices for shops and supermarkets

Similar forms can be used to collect prices of other food items

\begin{tabular}{|c|c|c|c|c|c|}
\hline \multicolumn{6}{|c|}{ Modify to include main cereals for local area } \\
\hline \multicolumn{6}{|c|}{ CEREALS (e.g. rice, maize, wheat, sorghum, bread, noodles) } \\
\hline Market place & & & \multicolumn{2}{|c|}{ Investigator } & \\
\hline Seller name & & & \multicolumn{2}{|c|}{ Date completed } & \\
\hline Seller address & & & \multicolumn{2}{|c|}{ Time completed } & \\
\hline Rice brand \& quality & Size in $\mathrm{kg}$ & Price & \multicolumn{2}{|c|}{ Price per $\mathrm{kg}$} & $\begin{array}{l}\text { On sale? } \\
\quad \text { (indicate } \\
\text { if yes) }\end{array}$ \\
\hline \multicolumn{6}{|l|}{$\begin{array}{l}\text { Wheat brand \& } \\
\text { quality }\end{array}$} \\
\hline \multicolumn{6}{|l|}{$\begin{array}{l}\text { Maize brand \& } \\
\text { quality }\end{array}$} \\
\hline \multicolumn{6}{|l|}{$\begin{array}{l}\text { Noodle brand \& } \\
\text { quality }\end{array}$} \\
\hline $\begin{array}{l}\text { Bread brand \& } \\
\text { quality }\end{array}$ & $\begin{array}{l}\text { Weight } \\
\text { of loaf in } \\
\text { grams }\end{array}$ & $\begin{array}{c}\text { Price of } \\
\text { loaf }\end{array}$ & $\begin{array}{l}\text { Price } \\
\quad \text { per kg }\end{array}$ & $\begin{array}{l}\text { Number } \\
\text { of } \\
\text { slices }\end{array}$ & $\begin{array}{l}\text { On sale? } \\
\quad \text { (indicate } \\
\text { if yes) }\end{array}$ \\
\hline Buns (indicate type) & $\begin{array}{l}\text { Weight } \\
\text { of bun }\end{array}$ & $\begin{array}{l}\text { Price per } \\
\text { bun }\end{array}$ & $\begin{array}{l}\text { Price per } \\
\mathrm{kg}\end{array}$ & & $\begin{array}{l}\text { On sale? } \\
\quad \text { (indicate } \\
\text { if yes) }\end{array}$ \\
\hline & & & & & \\
\hline
\end{tabular}

